\title{
GROWTH AND FLUORESCENCE OF 'TAHITI' ACID LIME/ROOTSTOCK ON SUNKI MANDARIN HYBRIDS UNDER SALINITY
}

\author{
CRESCIMENTO E FLUORESCÊNCIA DE LIMEIRA ÁCIDA 'TAHITI' \\ ENXERTADA EM HÍBRIDOS DE TANGERINEIRA SUNKI SOB SALINIDADE
}

\author{
Luderlândio de Andrade SILVA ${ }^{1 *}$; Marcos Eric Barbosa BRITO ${ }^{2,7}$; \\ Pedro Dantas FERNANDES ${ }^{3,7}$; Francisco Vaniés da Silva SÁ ${ }^{4}$; \\ Rômulo Carantino Lucena MOREIRA ${ }^{1}$; Giuliana Naiara Barros SALES; \\ Juliana Formiga ALMEIDA ${ }^{5}$; Walter dos Santos SOARES FILHO ${ }^{6,7}$;
}

1. Doctorate in Agricultural Engineering, Federal University of Campina Grande - UFCG, Campina Grande, PB, Brazil. luderlandioandrade@gmail.com; 2. Doctor in Agricultural Engineering, Teacher, Federal University of Sergipe, Campus do Sertão; Nossa Senhora da Glória, SE, Brazil; 3. Doctor in Soil and Plant Nutrition, Visiting Teacher, UFCG, Campina Grande, PB, Brazil; 4. Doctor in Agricultural Engineering, Postdoctoral Fellow of the National Postdoctoral Program, Federal Rural Semi-Arid University, Mossoró, RN, Brazil; 5. Master's degree in Tropical Horticulture, UFCG, Pombal, PB, Brazil; 6. Doctor in Agronomy, Researcher A of Embrapa Cassava \& Fruits, Cruz das Almas, BA, Brazil; 7. CNPq PQ scholarship holder.

\begin{abstract}
The objective of this study was to evaluate the ecophysiological behavior of 'Tahiti' acid lime/rootstock grafted on Sunki mandarin hybrids during the prefloration stage of the plants, in the field, under saline stress. The progenies originating from crossings of the 'Sunki' mandarin with 'Rangpur' lime and Poncirus trioliata, as rootstocks, combined with the 'Tahiti' acid lime as a scion. The experiment was carried out under field conditions, at the Federal University of Campina Grande (UFCG), Pombal PB fields. In drainage lysimeter of $150 \mathrm{dm}^{3}$, studying $10 \mathrm{scion} /$ rootstock combinations, irrigated with two water salinity levels $(\mathrm{CEa})\left(\mathrm{S} 1=0.3\right.$ and $\left.\mathrm{S} 2=3.0 \mathrm{dS} \mathrm{m} \mathrm{m}^{-1}\right)$ making a $10 \times 2$ factorial scheme. The experimental design was a randomized block design, with 3 replicates and each plot consisting of a useful plant, totalizing 60 parcels. The scion/rootstock plants were transplanted at one year of age from the rootstocks sowing, being the beginning of the applications of the saline stress to the 15 days after the transplant lasting until the period of flowering, that is, up to 195 days after transplanting, During this period the plants were analyzed for growth and chlorophyll fluorescence $a$. The combinations less sensitive to salinity were composed of the 'Tahiti' grafted with TSKFL $\mathrm{x}$ (LCR x TR) - 018, TSKFL x TRBK - 011 and TSKFL x TRBK - 030, it being possible to use saline water with up to $3.0 \mathrm{dS} \mathrm{m}$ m $^{-1}$ in irrigation. Salinity did not damage the biochemical phase of the scion/rootstock combinations, only affecting the initial fluorescence of the lighted tissue.
\end{abstract}

KEYWORDS: Citrus spp. Genetic improvement. Ecophysiology. Irrigation. Salinity.

\section{INTRODUCTION}

Brazil stands out as the largest citrus producer of the world, and its Northeast region is the second largest in the country, with great socioeconomic relevance related to job and income generation. Nonetheless, the yield is below the potential of the crop, since the mean is $11.8 \mathrm{t} \mathrm{ha}^{-1}$ (IBGE, 2016), which can be attributed to the use of less productive scion/rootstock combinations and to the natural water deficit occurring in the hottest months of the year. This leads to the necessity of using irrigation systems to increase the production, as observed by Braz et al. (2009), studying the effect of irrigation frequency and depth on 'Tahiti' acid lime [Citrus latifolia (Yu. Tanaka) Tanaka].

Besides the natural water deficit of this region, salt concentrations are relatively high in the water sources because rainfalls are irregular and insufficient to wash out the salts and due to the contribution from the parent material (AUDRY; SUASSUNA, 1995; SANTOS, 2008; OLIVEIRA et al., 2010). Using these waters in irrigation can reduce growth, development and yield of citrus plants, since they are considered as sensitive to salinity (MASS, 1993; LEVY; SYVERTSEN, 2004; ZHAO et al., 2007).

Despite that, the literature has reported genotypes used as rootstocks with potential tolerance to salinity (FERNANDES et al., 2011 HUSSAIN et al., 2012; SILVA et al., 2012; HUSSAIN et al., 2015; BRITO et al., 2016). However, to identify salt-tolerant citrus genotypes, successive evaluations must be conducted and need to encompass the entire crop production system. For citrus, firstly, it is necessary to identify tolerant materials during the stages of rootstock growth (BRITO et al., 2008; FERNANDES et al., 2011), 
grafted seedling growth (BRITO et al., 2014; BRITO et al., 2015). Then, these materials with potential need to be taken to the field to consolidate the recommendation, based on growth and physiological variables, which are of great importance.

In the evaluation of the different responses of citrus genotypes in the rootstock phase, to the effects of salinity, studies on growth, photosynthesis and fluorescence of chlorophyll have been shown to be successful in the identification of genotype tolerat, that develops mechanisms physiological of perception and/or adaptation to salt stress (SULVA et al., 2014; BARBOSA et al., 2017; SÁ et al., 2018).

Therefore, the objective was to evaluate growth and chlorophyll fluorescence in 'Tahiti' acid lime grafted onto 'Sunki' mandarin hybrids under water salinity during the pre-flowering stage.

\section{MATERIAL AND METHODS}

The experiment was carried out from February to August 2016, at the Center of Sciences and Agri-food Technology - CCTA of the Federal University of Campina Grande - UFCG, located in the municipality of Pombal, $\mathrm{PB}$, at geographic coordinates $6^{\circ} 47^{\prime} 20^{\prime \prime} \mathrm{S}$ and $37^{\circ} 48^{\prime} 01^{\prime}$ ' W, at altitude of $194 \mathrm{~m}$.

Temperature and rainfall were recorded along the experimental period. Maximum temperature varied between 30 and $39^{\circ} \mathrm{C}$, minimum temperature varied between 15 and $26^{\circ} \mathrm{C}$, and their respective mean values were $34.1 \pm 1.3$ and $21.4 \pm 2.0$ ${ }^{\circ} \mathrm{C}$, measured from February to August 2016, a period from the beginning of the experiment to the end of the pre-flowering stage.

Rains were concentrated in March and some events occurred in April and June, amounting for a volume of $264 \mathrm{~mm}$, which is insufficient to guarantee high yields because the citrus crop requires between 600 and $1300 \mathrm{~mm}$ according to the literature (Mattos Junior et al., 2005). Thus, it was necessary to replace $100 \%$ of crop evapotranspiration $(\mathrm{ETc})$, considering the water balance in the soil.

Treatments were arranged in randomized blocks, in a $10 \times 2$ factorial scheme, corresponding to 10 combinations between 'Tahiti' acid lime and ten rootstocks, irrigated with two levels of water salinity, 0.3 and $3.0 \mathrm{dS} \mathrm{m} \mathrm{m}^{-1}$. All factors combined led to 20 treatments (10 combinations x 2 salinity levels), repeated in three blocks, and each plot consisted of one plant, totaling 60 plots.
The genotypes used as rootstocks came from the Citrus Breeding Program of Embrapa Cassava and Fruits, namely: five genotypes from the cross 'Sunki' mandarin C. sunki (Hayata) hort. ex Tanaka [three of the common selection (TSKC) and two of the 'Florida' selection (TSKFL)] $x$ ['Rangpur' lime (LCR) (C. limonia Osbeck) $\mathrm{x}$ Poncirus trifoliata (L.) Raf. (TR)]; four genotypes from the cross TSKFL $\times[P$. trifoliata Benecke (TRBK)]; and 'Santa Cruz Rangpur' lime (LCRSTC), used as control, because 'Rangpur' lime is the main rootstock in Brazilian citrus industry.

Apogamic rootstocks seedlings (nucellar) were arranged in 2-L plastic bags and, after acclimation to the region, they were transplanted to 5-L bags. Initially, the seedlings were conducted with a stake and, after reaching $50 \mathrm{~cm}$ height, they were pruned, allowing three branches to grow, thus forming a small-crown seedling, which was transplanted to the lysimeters at 365 days after sowing (DAS).

The lysimeters had a volume of $150 \mathrm{~L}$ and were painted white to increase the reflectance and reduce heat conservation in the soil, being arranged in the field at $2 \times 2 \mathrm{~m}$ spacing, since 'Tahiti' acid lime was going to be planted and cultivation practices were going to be manually carried out.

The lysimeters were filled with soil collected at the UFCG's experimental farm, in the municipality of São Domingos, PB, classified as Fluvic NEOSOL, based on the characterization of diagnostic horizons and on samples collected from 0 to $0.2 \mathrm{~m}$ and from 0.2 to $0.4 \mathrm{~m}$.

In the filling process, $15 \mathrm{~L}$ of crushed stone and sand, 8 and $7 \mathrm{~L}$ respectively, were used to form a 0.04-m-thick layer at the bottom of the lysimeter, to facilitate the drainage of excess water. On top of this layer, a planting hole as in the field was simulated using a cylinder $(40 \mathrm{~cm}$ diameter; $40 \mathrm{~cm}$ height). A mixture of $40 \mathrm{~L}$ of soil $+20 \mathrm{~L}$ of aged bovine manure was placed inside it and $60 \mathrm{~L}$ of soil were put outside it, totaling $135 \mathrm{~L}$. After filling, the cylinder was removed.

Phosphate fertilization was applied in the planting hole using single superphosphate and, immediately after, a mulch layer with $1 \mathrm{~kg}$ of corn straw was placed on top to reduce evaporation. Garden grass was planted in the rows between the lysimeters to try to form a microclimate, decreasing the temperature.

Irrigations were daily applied through a localized system using drip tapes with regulated flow rate of $1.9 \mathrm{~L} \mathrm{~h}^{-1}$ per dripper; five drippers were used per plant, to help fixing the drip tape in each lysimeter. Until 15 days after transplantation, plants 
received water with low electrical conductivity $\mathrm{ECw}\left(0.3 \mathrm{dS} \mathrm{m}^{-1}\right)$ from the local supply system. After that, solutions with the different $\mathrm{ECw}$ levels were applied until the pre-flowering stage.

Irrigation management was based on the water balance method, replacing the mean daily water consumption. Every week, plant water consumption was added of a leaching fraction, corresponding to the division of the volume consumed during the week (L) by 0.9 , to obtain a leaching fraction of 0.10 , which allowed to remove part of the salts accumulated in the root zone. To collect the drained water, the $18-\mathrm{mm}$ valve installed at the bottom of each lysimeter was connected to a hose, which allowed the drained water to flow to an 18-L plastic container.

Nutritional management followed the recommendations proposed by Mattos Junior et al. (2005), considering soil and manure analyses and taking all the other cautions of management recommended for citrus production systems.

Table 1 Chemical characteristics of the soil used to fill the lysimeters cultivated with citrus plants.

\begin{tabular}{|c|c|c|c|c|c|c|c|c|c|c|c|}
\hline & \multirow{2}{*}{$\begin{array}{l}\mathrm{pH} \\
\mathrm{CaCl} 2 \text { 1: }\end{array}$} & \multirow{2}{*}{$\begin{array}{l}\text { E.C. } \\
\text { dS/m }\end{array}$} & \multirow{2}{*}{$\begin{array}{l}\mathrm{P} \\
\mathrm{mg} / \mathrm{dm}^{3}\end{array}$} & \multirow{2}{*}{$\begin{array}{l}\mathrm{N} \\
\%\end{array}$} & $\mathrm{~K}$ & $\mathrm{Na}$ & $\mathrm{Ca}$ & $\mathrm{Mg}$ & \multirow{2}{*}{\multicolumn{2}{|c|}{$\begin{array}{l}\mathrm{BS} \quad(\mathrm{t}) \\
\mathrm{cmolc} / \mathrm{dm}^{3}\end{array}$}} & \multirow{2}{*}{$\begin{array}{l}\text { O.M. } \\
\text { g/Kg }\end{array}$} \\
\hline & & & & & \multicolumn{4}{|c|}{$\mathrm{cmolc} / \mathrm{dm}^{3}$} & & & \\
\hline Soil & 7,26 & 0,03 & 7 & 0,16 & 0,52 & 0,36 & 4,55 & 2,35 & 7,79 & 7,42 & 3 \\
\hline Manure & 6,47 & 1,09 & 98 & 2,44 & 3,82 & 1,54 & 4,52 & 2,63 & 12,51 & 10,97 & 40 \\
\hline
\end{tabular}

The irrigation solution relative to the second saline level $\left(3.0 \mathrm{dS} \mathrm{m}^{-1}\right)$ was prepared by adding $\mathrm{NaCl}$ to the public-supply water $\left(\mathrm{ECw}=0.3 \mathrm{dS} \mathrm{m}^{-}\right.$ ${ }^{1}$ ), considering the relationship between $\mathrm{ECw}$ and concentration of salts $\left(10^{*} \mathrm{meq} \mathrm{L}^{-1}=1 \mathrm{dS} \mathrm{m} \mathrm{m}^{-1}\right.$ of ECw) according to Rhoades et al. (1992), valid for $\mathrm{ECw}$ from 0.1 to $5.0 \mathrm{dS} \mathrm{m}^{-1}$, which encompass the level to be prepared.

After preparation, the solutions were stored in 500-L plastic containers, one for each $\mathrm{ECw}$ level studied, and properly protected to avoid evaporation, entry of rainwater and contamination with materials that could compromise their quality. $\mathrm{ECw}$ was measured before each irrigation using a portable conductivity meter, with conductivity adjusted to the temperature of $25^{\circ} \mathrm{C}$.

At 60,120 and 180 days after the stress began (DASB), chlorophyll $a$ fluorescence was measured using an Opti Science OS5p pulsemodulated fluorometer. The $\mathrm{Fv} / \mathrm{Fm}$ protocol was used to determine the fluorescence induction parameters: Initial fluorescence (Fo), Maximum fluorescence $(\mathrm{Fm})$, Variable fluorescence $(\mathrm{Fv}=\mathrm{Fm}$ Fo) and maximum efficiency of photosystem II (Fv/Fm) (GENTY et al., 1989). This protocol was carried out after dark adaptation of leaves for 12 hours, in the morning before, using a clip from the device to make sure all primary acceptors were fully oxidized.

The pulse-modulated fluorometer was also used to perform evaluations under conditions of light, using the 'Yield' protocol, by applying an actinic light source with multi-flash saturation pulse, attached to a clip to measure photosynthetically active radiation (PAR-Clip), to determine the following parameters: initial fluorescence before saturation pulse $\left(F^{\prime}\right)$, maximum fluorescence after adaptation to saturation light (Fm'), electron transport rate (ETR) and quantum efficiency of photosystem II ( $\left.\mathrm{Y}_{\mathrm{II}}\right)$. These results were used to determine the following parameters: minimum fluorescence of the light-adapted plant tissue (Fo'); Photochemical quenching coefficient according to the "lake" model (qL); quantum yield of regulated photochemical quenching $\left(\mathrm{Y}_{\mathrm{NPQ}}\right)$, and quantum yield of non-regulated photochemical quenching $\left(\mathrm{Y}_{\mathrm{NO}}\right)$.

Every 30 days, counted from the beginning of the application of irrigation water salinity levels, stem diameter was measured in the rootstock, grafting point and scion, and the number of leaves was counted. Rootstock stem diameter was measured at the base of the plant, whereas scion stem diameter was measured $2 \mathrm{~cm}$ above the grafting point. All diameters were measured with a digital caliper, and the results were expressed in millimeters $(\mathrm{mm})$.

The obtained data were subjected to analysis of variance by $\mathrm{F}$ test. In cases of significance, means grouping test (Scott-Knott, $\mathrm{p}<0.05$ ) was applied for the scion/rootstock combinations at each level of water salinity (FERREIRA, 2011).

\section{RESULTS}

Among growth parameters, the interaction between scion/rootstock combinations and water salinity had significant effect $(\mathrm{p}<0.05)$ only on the number of leaves (Table 2).

Considering the factor scion/rootstock combinations, there were differences in stem diameter (SD-Rt) between genotypes in all studied periods, which also occurred for stem diameter at the grafting point (SD-Gp) at 60,90, 120 and 180 DASB. For scion stem diameter (SD-Sc), differences between the combinations occurred from 
90 DASB (Table 2). The genotypes differed with respect to the number of leaves at 30 and 180 DASB.

The effect of water salinity on plants was observed from 150 DASB through the analysis of stem diameter at the grafting point, scion stem diameter and number of leaves (Table 2).
Regarding chlorophyll fluorescence in the dark-adapted condition, no significant effect $(p<0.05)$ was caused by the interaction between scion/rootstock combinations and water salinity, and each of these factors alone caused no effect either (Table 3).

Table 2. Summary of analysis of variance for rootstock stem diameter (SD-Rt), stem diameter at the grafting point (SD-Gp), scion stem diameter (SD-Sc) and number of leaves (NL) at 30, 60, 90, 120, 150 and 180 days after the beginning of saline water application.

\begin{tabular}{|c|c|c|c|c|c|c|c|c|}
\hline \multirow[b]{2}{*}{$\begin{array}{l}\text { Sources of } \\
\text { variation }\end{array}$} & \multicolumn{8}{|c|}{ Medium Square } \\
\hline & $\begin{array}{l}\text { Period } \\
\text { (DAS) }\end{array}$ & $\begin{array}{l}\text { Genotypes } \\
\text { (G) }\end{array}$ & $\begin{array}{l}\text { Salinity } \\
\text { (S) }\end{array}$ & $\mathrm{G} \times \mathrm{S}$ & BLOKC & ERROR & MÉAN & $\begin{array}{l}\mathrm{CV} \\
(\%)\end{array}$ \\
\hline \multirow{6}{*}{ SD-Rt } & 30 & $9.827^{* *}$ & $0.342^{\mathrm{ns}}$ & $0.939^{\text {ns }}$ & $4.128^{\mathrm{ns}}$ & 1.581 & 11.549 & 10.89 \\
\hline & 60 & $18.329^{* *}$ & $3.672^{\mathrm{ns}}$ & $2.577^{\mathrm{ns}}$ & $8.438^{\text {ns }}$ & 3.554 & 14.457 & 13.04 \\
\hline & 90 & $27.507^{* *}$ & $0.110^{\mathrm{ns}}$ & $3.006^{\mathrm{ns}}$ & $8.048^{\text {ns }}$ & 3.450 & 17.513 & 10.61 \\
\hline & 120 & $31.825^{* *}$ & $0.518^{\mathrm{ns}}$ & $2.141^{\mathrm{ns}}$ & $12.758^{\mathrm{ns}}$ & 5.597 & 20.393 & 11.60 \\
\hline & 150 & $42.880^{* *}$ & $23.381^{\mathrm{ns}}$ & $4.923^{\text {ns }}$ & $10.544^{\mathrm{ns}}$ & 5.855 & 24.092 & 10.04 \\
\hline & 180 & $51.469^{* *}$ & $19.091^{\mathrm{ns}}$ & $4.314^{\mathrm{ns}}$ & $19.610^{\mathrm{ns}}$ & 5.497 & 26.429 & 8.87 \\
\hline \multirow{6}{*}{ SD-Gp } & 30 & $2.381^{\mathrm{ns}}$ & $0.463^{\text {ns }}$ & $2.035^{\text {ns }}$ & $2.399^{\text {ns }}$ & 1.670 & 13.378 & 9.66 \\
\hline & 60 & $6.951^{*}$ & $0.004^{\mathrm{ns}}$ & $2.822^{\mathrm{ns}}$ & $5.849^{\text {ns }}$ & 2.476 & 16.062 & 9.80 \\
\hline & 90 & $13.393^{* *}$ & $0.028^{\mathrm{ns}}$ & $2.897^{\mathrm{ns}}$ & $8.075^{\mathrm{ns}}$ & 3.475 & 19.406 & 9.61 \\
\hline & 120 & $12.452^{*}$ & $7.808^{\text {ns }}$ & $6.127^{\mathrm{ns}}$ & $6.052^{\text {ns }}$ & 4.489 & 22.293 & 9.50 \\
\hline & 150 & $13.488^{\mathrm{ns}}$ & $31.631^{*}$ & $6.650^{\mathrm{ns}}$ & $8.976^{\text {ns }}$ & $\begin{array}{l}4.409 \\
6.490\end{array}$ & 25.373 & 10.04 \\
\hline & 180 & $20.449^{* *}$ & $36.746^{*}$ & $6.642^{\mathrm{ns}}$ & $4.084^{\mathrm{ns}}$ & 5.672 & 28.087 & 8.48 \\
\hline \multirow{6}{*}{$\mathrm{SD}-\mathrm{Sc}$} & 30 & $1.347^{\mathrm{ns}}$ & $0.196^{\mathrm{ns}}$ & $1.057^{\mathrm{ns}}$ & $1.395^{\mathrm{ns}}$ & 0.762 & 9.918 & 8.80 \\
\hline & 60 & $2.788^{\text {ns }}$ & $0.011^{\mathrm{ns}}$ & $2.631 \mathrm{~ns}$ & $0.552^{\text {ns }}$ & 1.361 & 12.257 & 9.52 \\
\hline & 90 & $5.569^{*}$ & $0.295^{\text {ns }}$ & $2.796^{\mathrm{ns}}$ & 2.456 & 2.456 & 15.214 & 10.30 \\
\hline & 120 & $9.773^{* *}$ & $1.030^{\mathrm{ns}}$ & $4.614^{\mathrm{ns}}$ & $4.604^{\mathrm{ns}}$ & 3.100 & 18.040 & 9.76 \\
\hline & 150 & $16.001^{*}$ & $35.737^{*}$ & $2.755^{\text {ns }}$ & $4.188^{\mathrm{ns}}$ & 5.928 & 21.073 & 11.55 \\
\hline & 180 & $14.222^{*}$ & $62.352^{* *}$ & $6.379^{\mathrm{ns}}$ & $13.188^{\mathrm{ns}}$ & 5.347 & 23.614 & 9.79 \\
\hline \multirow{6}{*}{ NL } & 30 & $3667.075^{* *}$ & $93.750^{\mathrm{ns}}$ & $493.564^{\mathrm{ns}}$ & $3134.466^{*}$ & 805.624 & 113.783 & 24.95 \\
\hline & 60 & $4044.118^{\text {ns }}$ & $64.066^{\mathrm{ns}}$ & $1056.325^{\mathrm{ns}}$ & $1598.616^{\text {ns }}$ & 1999.985 & 170.433 & 26.24 \\
\hline & 90 & $8254.444^{\mathrm{ns}}$ & $41.666^{\mathrm{ns}}$ & $2735.296 \mathrm{n}^{\mathrm{ns}}$ & $8081.016^{\mathrm{ns}}$ & 4755.525 & 246.666 & 27.96 \\
\hline & 120 & $29890.992^{\mathrm{ns}}$ & $10036.266^{\mathrm{ns}}$ & $7734.933^{\text {ns }}$ & $21519.650^{\mathrm{ns}}$ & 15069.755 & 372.200 & 32.98 \\
\hline & 150 & $51571.71^{\mathrm{ns}}$ & $150801.06^{*}$ & $15280.84^{\mathrm{ns}}$ & $54802.06^{\mathrm{ns}}$ & 29515.69 & 489.566 & 35.09 \\
\hline & 180 & $656469.600^{* *}$ & $144342.489^{* *}$ & $36666.415^{*}$ & $31512.467^{*}$ & 9104.660 & 649.933 & 14.68 \\
\hline DF & & 9 & 1 & 9 & 2 & 38 & - & - \\
\hline
\end{tabular}

Table 3. Summary of the analysis of variance for initial fluorescence (Fo), maximum fluorescence (Fm), variable fluorescence $(\mathrm{Fv})$ and maximum photochemical quantum efficiency of photosystem II $(\mathrm{Fv} / \mathrm{Fm})$ of citrus genotypes at 60,120 and 180 days after the beginning of saline water application.

\begin{tabular}{|c|c|c|c|c|c|c|c|c|}
\hline \multirow[b]{2}{*}{$\begin{array}{l}\text { Sources of } \\
\text { variation }\end{array}$} & \multicolumn{8}{|c|}{ Medium Square } \\
\hline & $\begin{array}{l}\text { Period } \\
\text { (DAS) }\end{array}$ & $\begin{array}{l}\text { Genotypes } \\
\text { (G) }\end{array}$ & $\begin{array}{l}\text { Salinity } \\
\text { (S) }\end{array}$ & G X S & BLOKC & ERROR & MÉAN & $\begin{array}{l}\mathrm{CV} \\
(\%)\end{array}$ \\
\hline \multirow{3}{*}{ Fo } & 60 & $399.646^{\mathrm{ns}}$ & $2444.816^{\mathrm{ns}}$ & $702.520^{\mathrm{ns}}$ & $3616.550^{\mathrm{ns}}$ & 671.269 & 231.850 & 11.17 \\
\hline & 120 & $1403.844^{\mathrm{ns}}$ & $2088.600^{\mathrm{ns}}$ & $954.637^{\mathrm{ns}}$ & $962.637^{\mathrm{ns}}$ & 929.757 & 200.133 & 15.24 \\
\hline & 180 & $591.585^{\mathrm{ns}}$ & $2331.266^{\mathrm{ns}}$ & $1063.525^{\mathrm{ns}}$ & $802.216^{\mathrm{ns}}$ & 997.058 & 212.633 & 14.85 \\
\hline \multirow{3}{*}{$F m$} & 60 & $4228.325^{\mathrm{ns}}$ & $10613.400^{\mathrm{ns}}$ & $11548.548^{\mathrm{ns}}$ & $18762.950^{\mathrm{ns}}$ & 7674.142 & 1006.700 & 8.70 \\
\hline & 120 & $17460.424^{\mathrm{ns}}$ & $4183.350^{\mathrm{ns}}$ & $6598.424^{\mathrm{ns}}$ & $21794.550^{\mathrm{ns}}$ & 9358.357 & 932.650 & 10.37 \\
\hline & 180 & $4841.362^{\mathrm{ns}}$ & $26460.000^{\mathrm{ns}}$ & $4321.629^{\mathrm{ns}}$ & $18715.316^{\mathrm{ns}}$ & 13424.562 & 981.533 & 11.80 \\
\hline \multirow{3}{*}{$F v$} & 60 & $2535.942^{\mathrm{ns}}$ & $2870.416^{\mathrm{ns}}$ & $11042.787^{\mathrm{ns}}$ & $6623.150^{\mathrm{ns}}$ & 6376.588 & 774.850 & 10.31 \\
\hline & 120 & $13433.572^{\mathrm{ns}}$ & $360.150^{\mathrm{ns}}$ & $7388.668^{\mathrm{ns}}$ & $19468.316^{\mathrm{ns}}$ & 9160.316 & 732.516 & 13.07 \\
\hline & 180 & $4015.970^{\mathrm{ns}}$ & $13083.266^{\mathrm{ns}}$ & $4608.044^{\mathrm{ns}}$ & $13680.050^{\mathrm{ns}}$ & 9339.786 & 786.900 & 12.57 \\
\hline \multirow{3}{*}{$F v / F m$} & 60 & $0.00016^{\mathrm{ns}}$ & $0.00050^{\mathrm{ns}}$ & $0.00103^{\mathrm{ns}}$ & $0.00018^{\mathrm{ns}}$ & 0.00059 & 0.7683 & 3.18 \\
\hline & 120 & $0.00216^{\mathrm{ns}}$ & $0.00005^{\mathrm{ns}}$ & $0.00295^{\mathrm{ns}}$ & $0.00235^{\mathrm{ns}}$ & 0.00266 & 0.7820 & 6.60 \\
\hline & 180 & $0.00052^{\mathrm{ns}}$ & $0.00019^{\mathrm{ns}}$ & $0.00104^{\mathrm{ns}}$ & $0.00047^{\mathrm{ns}}$ & 0.00051 & 0.7822 & 2.89 \\
\hline DF & & 9 & 1 & 9 & 2 & 38 & - & - \\
\hline
\end{tabular}

$*, * *=$ significant at 0.05 and 0.01 probability levels; $\mathrm{NS}=$ not significant; $\mathrm{DF}=$ degrees of freedom; $\mathrm{CV}=$ coefficient of variation. 
On the other hand, for the fluorescence parameters in the light-adapted condition, the interaction between genotypes and water salinity caused effect on the minimum fluorescence of the light-adapted tissue (Fo') (Table 4). In the followup analysis for the individual effects of the factors, the genotypes differed with respect to maximum fluorescence after saturating light (Fm') at 150 and 180 DASB. Water salinity caused significant effect only on Fo' at 60 DASB and on Fm' at 120 DASB (Table 4).

Based on the assumption that the effect of salinity is more evident according to the time and intensity of stress, a fact confirmed by the significant effect observed on the number of leaves at $180 \mathrm{DASB}$, we opted for describing plant growth based on the data obtained at 180 DASB but considering the effect of salinity on the genotypes, since the factors alone were significant in this period, and the degrees of freedom for treatment is relatively high. Thus, they could mask the individual effect of salinity on a certain genotype, not allowing for the distinction of the best combination.

Table 4. Minimum fluorescence of the light-adapted plant tissue (Fo'), maximum fluorescence after adaptation to saturating light (Fm'), initial fluorescence before saturation pulse (FS), quantum yield of regulated photochemical quenching $\left(\mathrm{Y}_{\mathrm{NPQ}}\right)$, quantum yield of non-regulated photochemical quenching $\left(\mathrm{Y}_{\mathrm{NO}}\right)$ and photochemical quenching coefficient according to the "lake" model (qL) of citrus genotypes at 60,120 and 180 days after the beginning of saline water application.

\begin{tabular}{|c|c|c|c|c|c|c|c|c|}
\hline \multirow{2}{*}{$\begin{array}{l}\text { Sources of } \\
\text { variation }\end{array}$} & \multicolumn{8}{|c|}{ Medium Square } \\
\hline & $\begin{array}{l}\text { Period } \\
\text { (DAS) }\end{array}$ & $\begin{array}{l}\text { Genotypes } \\
\text { (G) }\end{array}$ & $\begin{array}{l}\text { Salinity } \\
(\mathrm{S})\end{array}$ & $\mathrm{G} \times \mathrm{S}$ & BLOKC & ERROR & MÉAN & $\begin{array}{l}\mathrm{CV} \\
(\%)\end{array}$ \\
\hline \multirow{3}{*}{$F o^{\prime}$} & 60 & $399.646^{\mathrm{ns}}$ & $2444.816^{*}$ & $702.520^{\mathrm{ns}}$ & $3616.550^{\mathrm{ns}}$ & 671.269 & 231.850 & 11.17 \\
\hline & 120 & $1309.580^{\mathrm{ns}}$ & $1474.499^{\mathrm{ns}}$ & $1559.876^{\mathrm{ns}}$ & $548.400^{\mathrm{ns}}$ & 1211.111 & 197.650 & 17.61 \\
\hline & 180 & $1335.635^{\mathrm{ns}}$ & $1331.589^{\mathrm{ns}}$ & $1668.441^{*}$ & $196.325^{\mathrm{ns}}$ & 672.299 & 190.421 & 13.62 \\
\hline \multirow{3}{*}{$q L$} & 60 & $0.033^{\mathrm{ns}}$ & $0.120^{\mathrm{ns}}$ & $0.064^{\mathrm{ns}}$ & $0.218^{*}$ & 0.061 & 0.441 & 56.18 \\
\hline & 120 & $0.042^{\mathrm{ns}}$ & $0.018^{\mathrm{ns}}$ & $0.022^{\mathrm{ns}}$ & $0.027^{\mathrm{ns}}$ & 0.023 & 0.681 & 22.65 \\
\hline & 180 & $0.028^{\mathrm{ns}}$ & $0.018^{\mathrm{ns}}$ & $0.032^{\mathrm{ns}}$ & $0.038^{\mathrm{ns}}$ & 0.037 & 0.174 & 111.7 \\
\hline \multirow{3}{*}{$F^{\prime}$} & 60 & $18699.905^{\mathrm{ns}}$ & $8808.816^{\mathrm{ns}}$ & $26851.816^{\mathrm{ns}}$ & $77718.866^{*}$ & 21169.392 & 443.483 & 32.81 \\
\hline & 120 & $9931.555^{\mathrm{ns}}$ & $792.066^{\mathrm{ns}}$ & $8863.400^{\mathrm{ns}}$ & $3846.050^{\mathrm{ns}}$ & 5931.506 & 270.000 & 28.52 \\
\hline & 180 & 36239.476 & $2124.150^{\mathrm{ns}}$ & $16301.816^{\mathrm{ns}}$ & $19534.616^{\mathrm{ns}}$ & 36239.476 & 523.983 & 36.33 \\
\hline \multirow{3}{*}{$F m^{\prime}$} & 60 & $15662.600^{\mathrm{ns}}$ & $17957.400^{\mathrm{ns}}$ & $9726.585^{\mathrm{ns}}$ & $435.216^{\mathrm{ns}}$ & 16873.164 & 979.233 & 13.27 \\
\hline & 120 & $7153.896^{*}$ & $22893.066^{*}$ & $4845.140^{\mathrm{ns}}$ & $4566.066^{\mathrm{ns}}$ & 3357.610 & 861.266 & 6.73 \\
\hline & 180 & $94333.779^{*}$ & $10800.416^{\mathrm{ns}}$ & $30937.083^{\mathrm{ns}}$ & $17221.400^{\mathrm{ns}}$ & 42884.364 & 697.550 & 29.69 \\
\hline \multirow{3}{*}{$Y(N P Q)$} & 60 & $0.027^{\mathrm{ns}}$ & $0.018^{\mathrm{ns}}$ & $0.032^{\mathrm{ns}}$ & $0.102^{\mathrm{ns}}$ & 0.033 & 0.534 & 34.33 \\
\hline & 120 & $0.010^{\mathrm{ns}}$ & $0.001^{\mathrm{ns}}$ & $0.007^{\mathrm{ns}}$ & $0.007^{\mathrm{ns}}$ & 0.005 & 0.686 & 10.65 \\
\hline & 180 & $0.008^{\mathrm{ns}}$ & $0.001^{\mathrm{ns}}$ & $0.022^{\mathrm{ns}}$ & $0.002^{\mathrm{ns}}$ & 0.016 & 0.249 & 51.97 \\
\hline \multirow{3}{*}{$Y(N O)$} & 60 & $0.024^{\mathrm{ns}}$ & $0.016^{\mathrm{ns}}$ & $0.033^{\mathrm{ns}}$ & $0.079^{\mathrm{ns}}$ & 0.026 & 0.446 & 36.09 \\
\hline & 120 & $0.021^{\mathrm{ns}}$ & $0.001^{\mathrm{ns}}$ & $0.003^{\mathrm{ns}}$ & $0.001^{\mathrm{ns}}$ & 0.010 & 0.294 & 34.41 \\
\hline & 180 & $0.076^{\mathrm{ns}}$ & $0.000^{\mathrm{ns}}$ & $0.018^{\mathrm{ns}}$ & $0.044^{\mathrm{ns}}$ & 0.043 & 0.542 & 38.64 \\
\hline $\mathrm{DF}$ & & 9 & 1 & 9 & 2 & 38 & & \\
\hline
\end{tabular}

There was difference in rootstock stem diameter between combinations irrigated with 0.3 $\mathrm{dS} \mathrm{m}^{-1}$ water (Figure 1), forming two groups. The group with highest means comprised the hybrids TSKC $x($ LCR $x$ TR) -017 , TSKFL $x$ TRBK -011 , TSKFL $x$ TRBK -017 , TSKFL $x$ TRBK -028 and TSKFL $x$ TRBK -030 , whereas the group with lowest means comprised the hybrids TSKC or TSKFL x (LCR x TR) and LCRSTC (Figure 1).

When $\mathrm{ECw}$ level increased to $3.0 \mathrm{dS} \mathrm{m} \mathrm{m}^{-1}$, three groups of hybrids were formed. The group with largest diameters comprised 'Tahiti' acid lime scions grafted onto the hybrids TSKC $\mathrm{x}$ (LCR $\mathrm{x}$ TR) - 017 and TSKC x (LCR x TR) - 018 and all hybrids of the progeny TSKFL $x$ TRBK, whereas the group with lowest means comprised 'Tahiti' acid lime scions grafted onto the hybrids TSKC $\mathrm{x}$ (LCR x TR) - 032; TSKC x (LCR x TR) - 059 and TSKC $\times($ LCR $\times$ TR) -012 , besides the LCRSTC (Figure 1). 

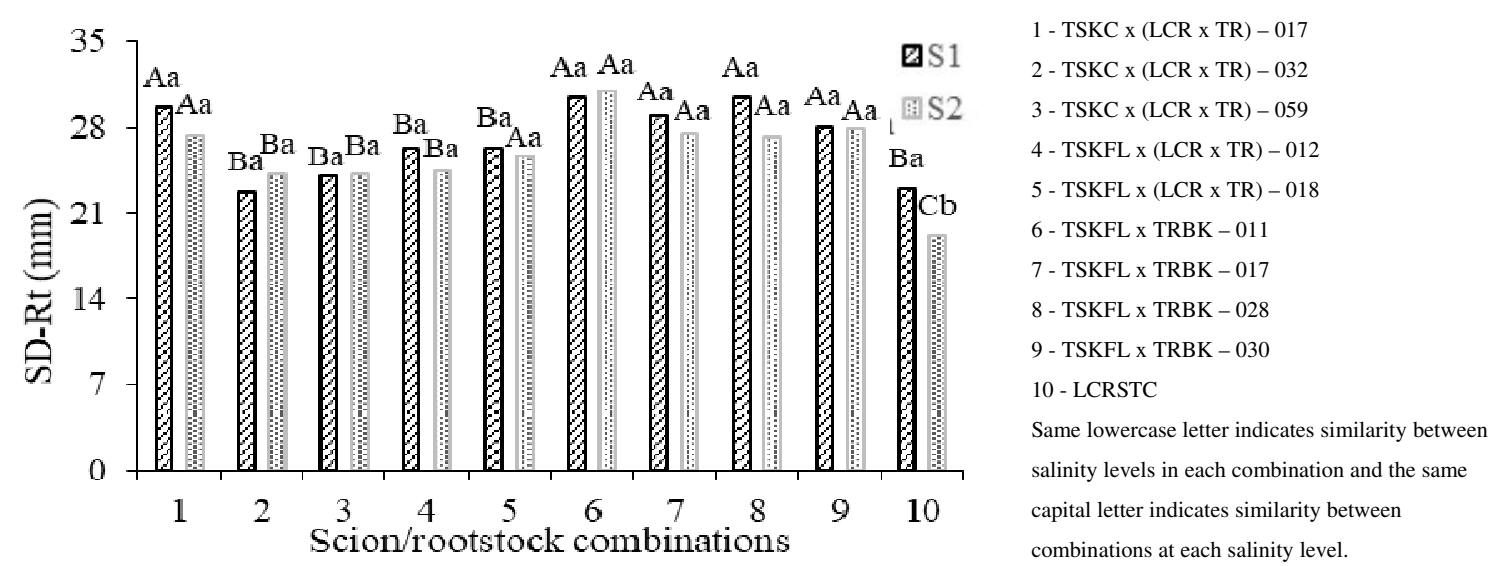

Figure 1. Rootstock stem diameter (SD-Rt) $(\mathrm{mm})$ for the combinations between 'Tahiti' acid lime and each rootstock at 180 days after the beginning of saline water application $\left(\mathrm{S} 1=0.3\right.$ and $\left.\mathrm{S} 2=3.0 \mathrm{dS} \mathrm{m}^{-1}\right)$ (DASB).

Analyzing stem diameter at the grafting point (SD-Gp) and in the scion at each salinity level, when water with lowest $\mathrm{ECw}\left(0.3 \mathrm{dS} \mathrm{m}^{-1}\right)$ was used in irrigation, there were no differences between the combinations (Figure 2 and 3). However, when 3.0 $\mathrm{dS} \mathrm{m}^{-1}$ water was used in irrigation, two groups were formed with respect to SD-Gp. The group with highest means contained the combinations between 'Tahiti' acid lime and the hybrids TSKC x (LCR x
TR) - 017, TSKC $x($ LCR $x$ TR) -059 , TSKFL $x$ (LCR $\times$ TR) - 012, TSKFL $\times($ LCR $\times$ TR) - 018, besides the hybrids TSKFL $x$ TRBK -011 , TSKFL $\mathrm{x}$ TRBK -017 and TSKFL $\mathrm{x}$ TRBK -030 . The group with lowest means was formed by the combinations with the genotypes TSKC $\mathrm{x}$ (LCR $\mathrm{x}$ TR) - 032, TSKFL $x$ TRBK - 028 and LCRSTC (Figure 3).

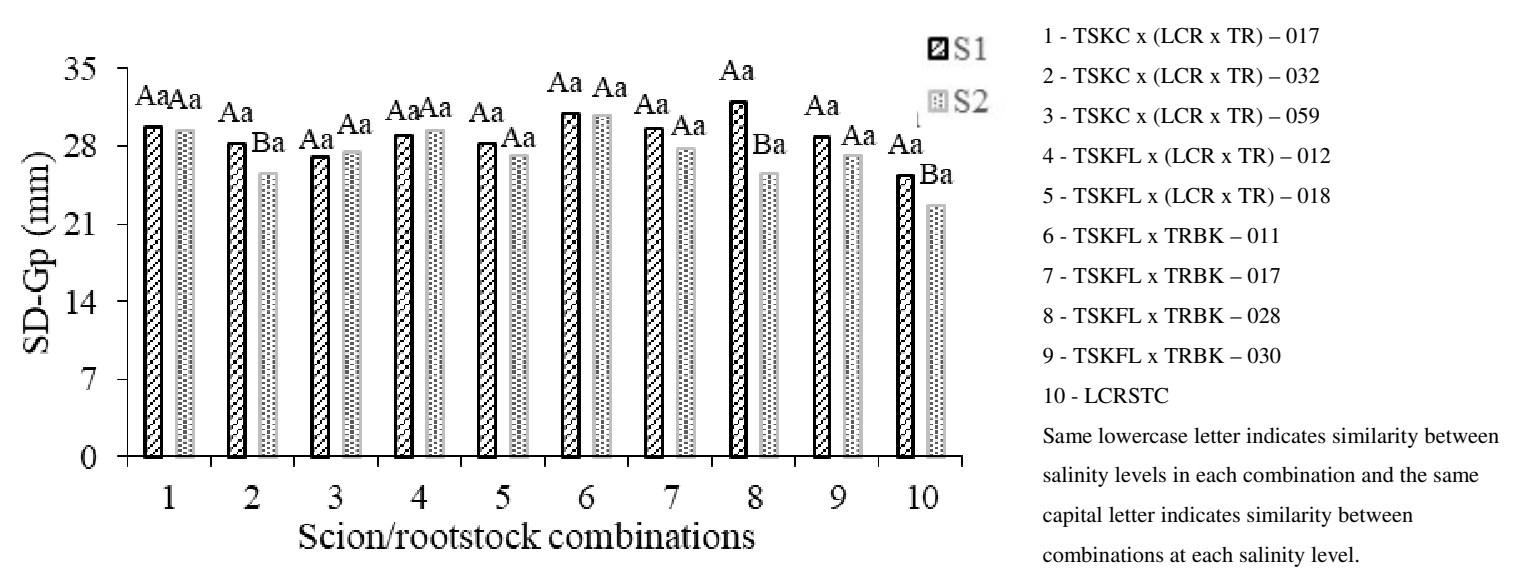

Figure 2. Stem diameter at the grafting point $(\mathrm{SD}-\mathrm{Gp})(\mathrm{mm})$ for the combinations between 'Tahiti' acid lime and each rootstock at 180 days after the beginning of saline water application $(\mathrm{S} 1=0.3$ and $\mathrm{S} 2=3.0$ $\mathrm{dS} \mathrm{m}^{-1}$ ) (DASB).

For scion stem diameter (SD-Sc) in plants irrigated with $3.0 \mathrm{dS} \mathrm{m} \mathrm{m}^{-1}$ water, two groups of genotypes were also formed. Highest means were observed in the combinations between 'Tahiti' acid lime and the hybrids TSKC x (LCR x TR) - 017, TSKFL $x$ (LCR $x$ TR) -012 , TSKFL $x$ (LCR $x$ TR) -018 and TSKC $x$ TRBK -011 , which varied from 23.32 to $26.19 \mathrm{~mm}$.
In general, water salinity did not cause significant reduction in the evaluated stem diameters; however, for the scion stem diameter of 'Tahiti' acid lime grafted onto the hybrids TSKC $\mathrm{x}$ (LCR $x$ TR) - 032 and TSKC $\times$ TRBK - 028, the effect of salinity significantly reduced stem diameter, by $17.36 \%$ and $23.98 \%$, respectively. 

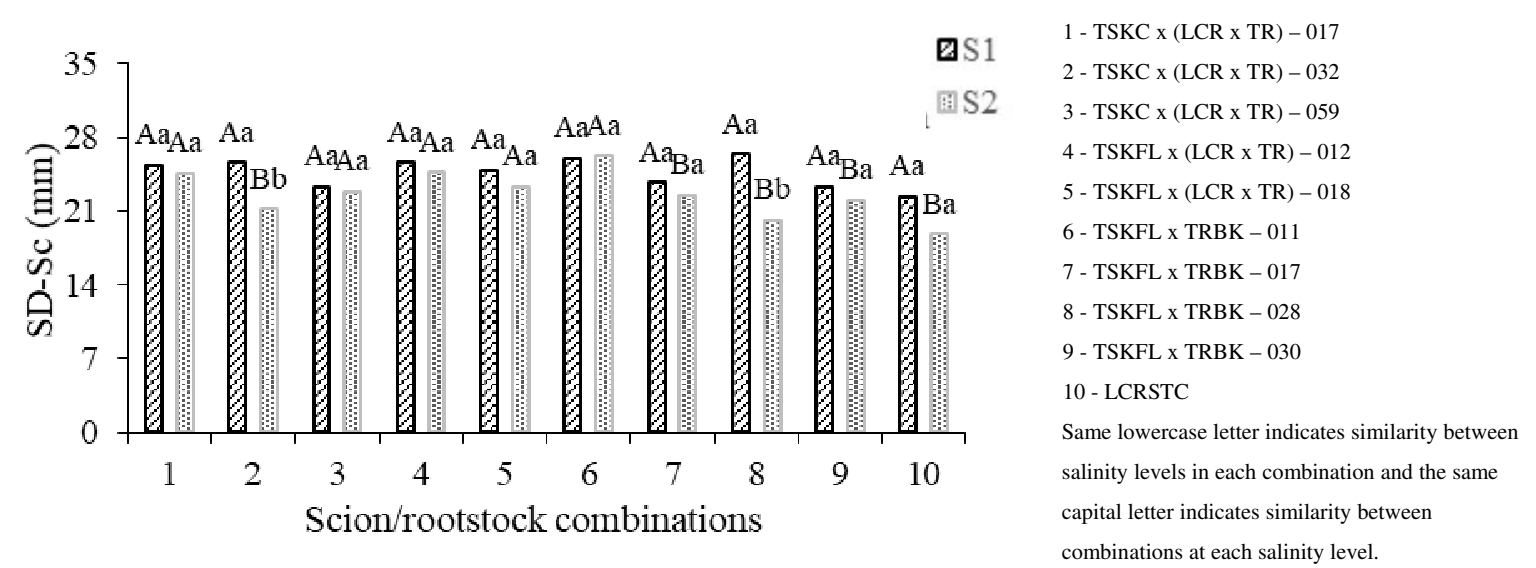

Figure 3. Scion stem diameter $(\mathrm{SD}-\mathrm{Sc})(\mathrm{mm})$ for the combinations between 'Tahiti' acid lime and each rootstock at 180 days after the beginning of saline water application $\left(\mathrm{S} 1=0.3\right.$ and $\left.\mathrm{S} 2=3.0 \mathrm{dS} \mathrm{m}^{-1}\right)$ (DASB).

For the number of leaves, at the lowest $\mathrm{ECw}$ level, four groups of genotypes were formed. Highest means were observed in the combination between Tahiti lime and TSKFL x (LCR x TR) 012, whereas the group with lowest means comprised the combinations between 'Tahiti' acid lime and the genotypes TSKFL $\mathrm{x}$ (LCR $\mathrm{x}$ TR) 018, TSKFL $x$ TRBK -017 , TSKFL $x$ TRBK -030 and LCRSTC (Figure 4).

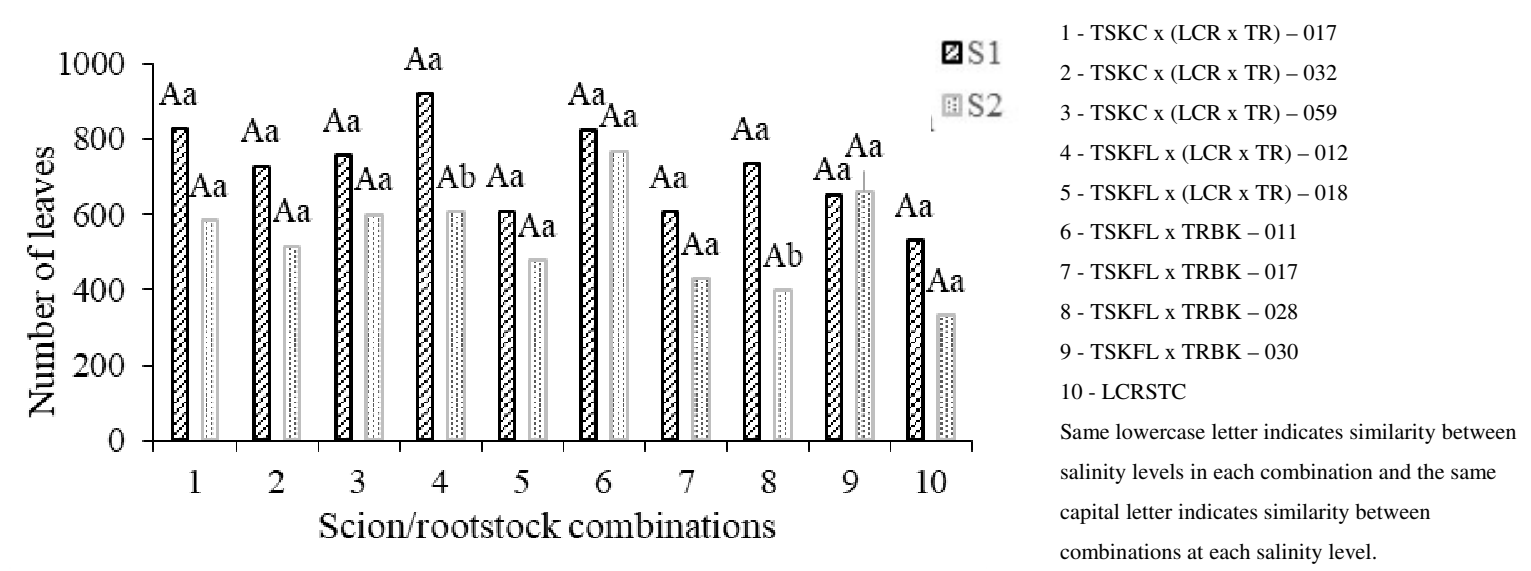

Figure 4. Number of leaves for the combinations between 'Tahiti' acid lime and each rootstock at 180 days after the beginning of saline water application $\left(\mathrm{S} 1=0.3\right.$ and $\left.\mathrm{S} 2=3.0 \mathrm{dS} \mathrm{m}^{-1}\right)(\mathrm{DASB})$.

When the combinations were irrigated with $3.0 \mathrm{dS} \mathrm{m}^{-1}$ water, there was a drastic reduction in the number of leaves, in general, forming two groups of genotypes according to the Scott-Knott. Highest means of number of leaves were found in the combinations between 'Tahiti' acid lime and the genotypes TSKC $\mathrm{x}($ LCR $\mathrm{x}$ TR) -017 , TSKC $\mathrm{x}$ (LCR $x$ TR) - 059, TSKFL $x$ TRBK -011 and TSKFL $x$ TRBK - 030, whereas the group with lowest means was formed by the combination of this scion and the other genotypes, especially LCRSTC.
Analyzing chlorophyll fluorescence through minimum fluorescence of the light-adapted tissue (Fo') at 60 DASB and maximum fluorescence after saturating light pulse (Fm') at 120 DASB, it was observed that the increase in water salinity led to increments of about 5.7 and $4.6 \%$, respectively (Figure 5).

For Fm', two groups of genotypes were formed (Table 5) according to the means grouping test (Scott-Knott), and lowest mean values occurred in the combinations with the hybrids TSKFL $\mathrm{x}$ (LCR $x$ TR) -018 and TSKFL $x$ TRBK -028 . 
A

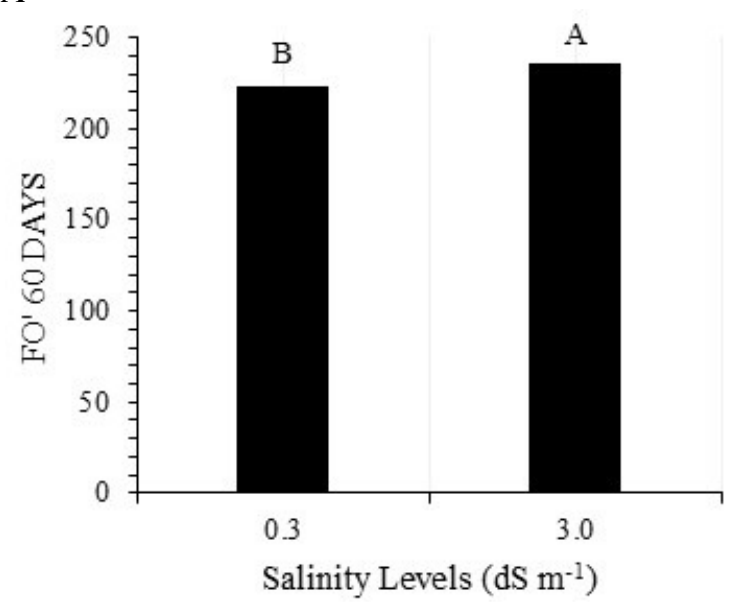

B

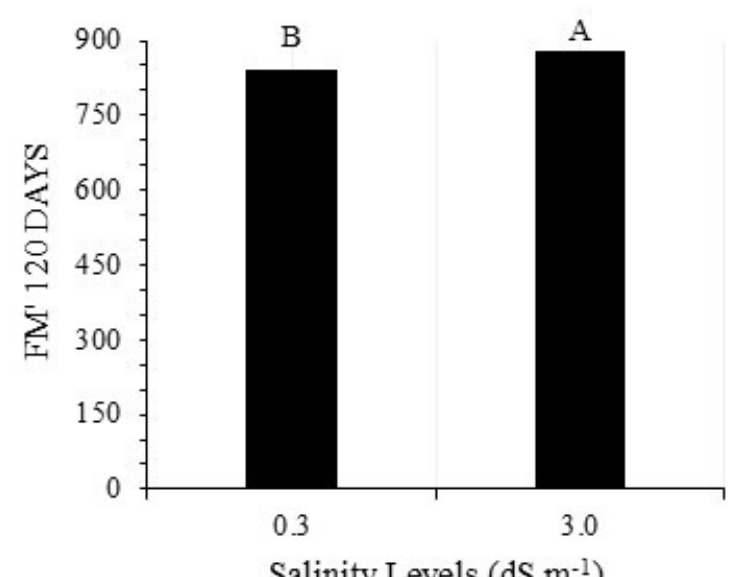

Figure 5. Means comparison test for minimum fluorescence of the light-adapted plant tissue - Fo' at 60 days after the beginning of saline stress (A) and maximum fluorescence after adaptation to saturating light - Fm' (B) at 120 days after the beginning of saline stress in the combinations between 'Tahiti' acid lime and different citrus rootstocks.

Table 5. Means grouping test for maximum fluorescence after adaptation to saturating light (Fm') at 120 days, minimum fluorescence of light-adapted plant tissue (Fo') at 180 days and maximum fluorescence after adaptation to saturating light (Fm') at 180 days after the beginning of saline water application.

\begin{tabular}{lllll}
\hline \multirow{2}{*}{ GEN } & $F M^{\prime} 120$ & \multicolumn{2}{c}{$F O^{\prime} 180$} & \multicolumn{2}{c}{$F M^{\prime} 180$} \\
\cline { 3 - 4 } & & $0.3 \mathrm{dS} \mathrm{m}^{-1}$ & $3.0 \mathrm{dS} \mathrm{m}^{-1}$ & $672.8333 \mathrm{~B}$ \\
TSKC X ( LCR x TR) - 017 & $873.0000 \mathrm{~A}$ & $187.2242 \mathrm{Ba}$ & $180.3167 \mathrm{Aa}$ & $833.8333^{\mathrm{a}}$ \\
TSKC X ( LCR x TR) - 032 & $849.5000 \mathrm{~A}$ & $192.4609 \mathrm{Ba}$ & $203.4645 \mathrm{Aa}$ & $504.3333 \mathrm{C}$ \\
TSKFL X ( LCR x TR) - 059 & $868.5000 \mathrm{~A}$ & $176.1691 \mathrm{Ca}$ & $170.6017 \mathrm{Aa}$ & $730.1666^{\mathrm{a}}$ \\
TSKFL X ( LCR x TR) - 018 & $870.3333 \mathrm{~A}$ & $187.2191 \mathrm{Ba}$ & $190.2446 \mathrm{Aa}$ & $816.6666^{\mathrm{a}}$ \\
TSKFL x TRBK - 011 & $790.0000 \mathrm{~B}$ & $199.9099 \mathrm{Ba}$ & $199.8941 \mathrm{Aa}$ & $630.0000 \mathrm{~B}$ \\
TSKFL x TRBK - 017 & $890.0000 \mathrm{~A}$ & $159.1347 \mathrm{Cb}$ & $227.3904 \mathrm{Aa}$ & $773.8333^{\mathrm{a}}$ \\
TSKFL x TRBK - 028 & $870.0000 \mathrm{~A}$ & $201.1705 \mathrm{Ba}$ & $193.0763 \mathrm{Aa}$ & $491.8333 \mathrm{C}$ \\
TSKFL x TRBK - 030 & $817.0000 \mathrm{~B}$ & $144.6588 \mathrm{Cb}$ & $192.3851 \mathrm{Aa}$ & $694.0000 \mathrm{~B}$ \\
LCRSTC & $907.5000 \mathrm{~A}$ & $163.8003 \mathrm{Ca}$ & $198.4559 \mathrm{Aa}$ & $828.0000 \mathrm{~A}$ \\
\hline
\end{tabular}

Different uppercase letters indicate significant difference between hybrids by Scott-Knott test at 0.05 probability level and different lowercase letters indicate significant difference for water salinity levels by Tukey test at 0.05 probability level.

In the evaluation at $180 \mathrm{DASB}$, there was greater difference in Fo' between the genotypes irrigated with $0.3 \mathrm{dS} \mathrm{m}^{-1}$ water, and three groups of genotypes were formed. Highest means were observed in the combinations of 'Tahiti' acid lime with the hybrids TSKC $\mathrm{x}$ (LCR $\mathrm{x}$ TR) -059 , TSKC $\mathrm{x}$ TRBK -011 , TSKC $\mathrm{x}$ TRBK -028 and TSKC $\mathrm{x}$ TRBK - 030, whereas the group with highest Fo' means contained the combination between 'Tahiti' acid lime and the LCRSTC.

Regarding Fm' data at 180 DASB, three groups of genotypes were formed and the lowest means occurred in the hybrids TSKC x (LCR x TR) - 059 and TSKC $x$ TRBK - 028. The group with highest means contained the hybrids TSKC X (LCR x TR $)-032$, TSKFL $X($ LCR $x$ TR $)-012$, TSKFL $X($ LCR $x$ TR $)-018$ and TSKFL $x$ TRBK -017 , besides the LCRSTC.

\section{DISCUSSION}

Difference between the combinations with respect to growth can be related to their capacity to acclimate to semi-arid conditions and/or genetic variation, although most of them have parental relationship, thus influencing the growth of the scion variety. Regarding salinity levels, expressive differences were only observed at 180 DASB, reinforcing the theory that the effect of salinity 
depends on time and intensity of the stress (BARBOSA et al., 2017).

Additionally, rains occurred in the first months of plant exposure to stress and diluted the salts in the soil, which may have provided conditions for plant to acclimate to the stress, as mentioned by Syvertsen and Garcia-Sanchez (2014). According to these authors, temperature and rainfall conditions can intensify or minimize saline stress in citrus. In this case, this observation is interesting for the citrus seedling planting program and, even under irrigation, it is necessary to prioritize citrus planting in periods with milder temperatures and occurrence of rainfall, as indicated by Mattos Junior et al. (2005).

Despite the degree of relationship among the materials, since most of them were crossed with Sunki mandarin, significant differences were found in the stem diameters measured in the rootstock, grafting point and scion. In addition, differences were observed in the number of leaves of the combinations when they were irrigated using water with electrical conductivity levels of 0.3 and $3.0 \mathrm{dS}$ $\mathrm{m}^{-1}$ (Figure 1, 2, 3 and 4). This fact may be related to genetic segregation and/or the capacity of each material to acclimate to semi-arid conditions.

Besides, such acclimation was evidenced by fluorescence data in the biochemical stage (Tables 3 ), when no significant effect of salinity was found, and in the photochemical stage, which means that, although there were effects on initial fluorescence and maximum fluorescence of light-adapted tissues, the photosynthetic apparatus was not damaged or needed to lose more energy through heat to regulate the photochemical process of photosynthesis (Tables 4).

For chlorophyll fluorescence after dark adaptation, when the primary acceptors were reduced, there were no damages to the photosynthetic and absence of losses in PSII quantum efficiency due to the increase in irrigation water salinity. This fact was evidenced by the lack of significant effect and, despite the reduction of growth, especially in the number of leaves, the effect of salinity can be related to osmotic disorders, which can also affect the photochemical stage of photosynthesis under light adaptation, as observed in the present study for the parameters initial fluorescence of the light-adapted tissue (Fo') and maximum fluorescence after saturating light pulse (Fm') (Table 4).

Additionally, the effects can be related to damages caused to the photosynthetic process due to the effects caused by salinity on the fluorescence of these materials, because an increment was found in the initial fluorescence (Table 5), which indicates damage to the photosynthetic apparatus and, consequently, reduction in plant growth capacity. Nonetheless, even with lower growth, the studied hybrids are promising because their means were higher than those of LCRSTC (Figure 4), the most planted genotype in the Brazilian citrus production (SILVA; SOUSA, 2002; BRITO et al., 2014)

It is worth highlighting that the increase in Fo' values (Figure $5 \mathrm{~A}$ ) indicates damage to the PSII reaction center (P680) or reduction in the initial capacity to transfer excitation energy from the PSII antenna, caused by the saline stress (BAKER; ROSENQVST, 2004; LUCENA, 2012; SILVA et al 2014; SÁ et al., 2015; BRITO et al., 2016). However, it was not followed by the significant increase in $\mathrm{qL}$ values, or led to significant reduction in photochemical yields, either regulated (YNPQ) or non-regulated (YNO), which confirms acclimation to stress, particularly in the combinations with TSKC x (LCR x TR) - 017, 059, TSKFL x TRBK 011 and TSKFL $x$ TRBK - 030, since these materials showed the smallest damages to the apparatus and greatest increase in the number of leaves, which can be an indication of potential tolerance to salinity.

Nonetheless, when Fm' values increase in plants irrigated with $3.0 \mathrm{dS} \mathrm{m}^{-1}$ water (Figure $5 \mathrm{~B}$ ), there is a compensation, which can be attributed to the energetic efficiency strategy of the plants, to increase variable fluorescence and maintain the quantum efficiency of photosystem II ( $\mathrm{Fv} / \mathrm{Fm})$, reducing the need for activation of photoprotection pathways, which would be identified by significant increase especially in the values of $\mathrm{qL}$ or $\mathrm{Y}_{\mathrm{NPQ}}$ (RIBEIRO, 2006).

It is should be pointed out that in some combinations, with the increase in the exposure to the highest salinity level, there were increments in Fo' and reductions in Fm', which means that the photochemical efficiencies were reduced, leading to losses of energy through heat and activation of photoprotective pathways of the photosystem. Rise in initial fluorescence is related to damages to the photosynthetic apparatus, indicating that the antenna system is not being able to hold the radiant energy, thus promoting greater energy dissipation and a consequent loss of efficiency in the photosynthetic apparatus (SILVA et al., 2014; BRITO et al., 2016). In this case, genotypes such as LCRSTC, which showed highest Fo' values and lowest increase in number of leaves, are less recommended for production in the semi-arid region than genotypes with potential tolerance. 


\section{CONCLUSIONS}

The combinations with highest growth under irrigation with $0.3 \mathrm{dS} \mathrm{m}^{-1}$ water were formed by 'Tahiti' acid lime grafted onto TSKC x (LCR x TR) - 017; TSKC x (LCR x TR) - 059, TSKC $x$ (LCR $\times$ TR) - 012; TSKFL $\times$ TRBK - 011, and TSKFL $x$ TRBK -28 ;
Water salinity did not cause damage to the photosynthetic apparatus of the citrus scionrootstock combinations evaluated;

It is possible to use saline water of up to 3.0 $\mathrm{dS} \mathrm{m}^{-1}$ in citrus cultivation, provided that a less sensitive combination is used, such as TSKC $\mathrm{x}$ (LCR x TR) - 017; TSKFL x (LCR x TR) - 059, TSKFL $x$ TRBK - 011, or TSKFL $x$ TRBK -30 .

RESUMO: Objetivou-se estudar o crescimento e a fluorescência da clorofila $a$ em limeira ácida 'Tahiti' enxertada em híbridos de tangerineira 'Sunki' sob salinidade da água durante a fase de préfloração das plantas. Assim, com base em um delineamento experimental de blocos ao acaso, foram avaliadas dez combinações copa/porta-enxerto, referentes à referida limeira ácida em combinação com dez porta-enxertos (nove híbridos e o limoeiro 'Cravo Santa Cruz' como testemunha), irrigadas com dois níveis de salinidade da água (CEa) $\left(\mathrm{S}_{1}=0,3\right.$ e $\left.\mathrm{S}_{2}=3,0 \mathrm{dS} \mathrm{m}^{-1}\right)$, perfazendo um esquema fatorial $10 \times 2$, que foi repetido em três blocos e com parcela constituída por uma planta útil, totalizando 60 parcelas. As mudas enxertadas foram transplantadas aos 365 dias após a semeadura dos porta-enxertos, em lisímetros de $150 \mathrm{dm}^{3}$, que foram preenchidos com um Neossolo Flúvico da região, sendo o início das aplicações do estresse salino aos 15 dias após o transplante (DAT), perdurando até o período de floração, ou seja, até os 195 DAT, avaliando o crescimento e a fluorescência da clorofila $a$. As combinações com maior crescimento quando irrigadas com água de condutividade de $0,3 \mathrm{dS}^{-1}$ foram aquelas com os porta-enxertos TSKC x (LCR x TR) - 017, TSKC x (LCR x TR) - 012, TSKFL $x$ (LCR x TR) - 018, TSKFL x TRBK - 011 e TSKFL x TRBK - 028. A salinidade não ocasionou dano à fase bioquímica das combinações copa/porta-enxerto, apenas afetado a fluorescência inicial do tecido iluminado. É possível usar água salina de até $3,0^{-1}$ no cultivo de citros, caso se empreguem combinações menos sensíveis, como aquelas tendo como porta-enxertos os híbridos TSKC x (LCR x TR) 017, TSKFL x (LCR x TR) - 018, TSKFL x TRBK - 011 e TSKFL x TRBK - 030.

PALAVRAS-CHAVE: Citrus spp. Melhoramento genético. Ecofisiologia. Irrigação. Salinidade.

\section{REFERENCES}

AUDRY, P.; SUASSUNA, J. A Salinidade das águas disponíveis para a pequena irrigação no sertão nordestino: caracterização, variação sazonal e limitações de uso. Recife: CNPq, 1995.128p.

BAKER, N. R.; ROSENQVST, E. Applications of chlorophyll fluorescence can improve crop production strategies: an examination of future possibilities. Journal of Experimental Botany, Oxford, v.55, n.403, p.16071621, Jul. 2004. https://doi.org/10.1093/jxb/erh196

BARBOSA, R. C. A.; BRITO, M. E. B.; SÁ, F. V. S.; SOARES FILHO, W. S.; FERNANDES, P. D.; SILVA, L. A. Gas exchange of citrus rootstocks in response to intensity and duration of saline stress. Semina: Ciências Agrárias, Londrina, v. 38, n. 2, P. 725-738, Mar-Apr. 2017. https://doi.org/10.5433/1679-0359.2017v38n2p725

BRAZ, V. B.; RAMOS, M. M.; ANDRADE JÚNIOR, A. S. de; SOUSA, C. A. F. de; MANTOVANI, E. C. Níveis e frequências de irrigação na limeira 'Tahiti' no Estado do Piauí. Revista Ceres, Viçosa, v. 56, n. 5, p. 611-619, Dec. 2009.

BRITO, M. E. B.; FERNANDES, P. D.; GHEYI, H. R.; MELO, A. S. de; CARDOSO, J. A. F.; SOARES FILHO, W. S. Sensibilidade de variedades e híbridos de citrange à salinidade na formação de porta-enxertos. Revista Brasileira de Ciências Agrárias, Recife, v. 3, n. 4, p 343-353, Oct-Dec. 2008. https://doi.org/10.5039/agraria.v3i4a364 
BRITO, M. E. B.; BRITO, K. S. A. de; FERNANDES, P. D.; GHEYI, H. R.; SUASSUNA, J. F.; SOARES FILHO, W. S.; MELO, A. S. de; XAVIER, D. A. Growth of ungrafted and grafted citrus rootstocks under saline water irrigation. African Journal and Agricultural Research, Brisbane, v. 9, n. 50, p. 3600-3609, Dec. 2014a.

BRITO, M. E. B.; FERNANDES, P. D.; GHEYI, H. R.; MELO, A. S.; SOARES FILHO, W. S.; SANTOS, R. T. Sensibilidade à salinidade de híbridos trifoliados e outros porta-enxertos de citros. Revista Caatinga, Mossoró, v. 27, n. 1, p. 17-27, Jan-Mar. 2014b.

BRITO, M. E. B.; SILVA, E. C. B. da; FERNANDES, P. D.; SOARES FILHO, W. DOS S.; COELHO FILHO, M.A.; SÁ, F. V. S.; MELO, A. S. de; BARBOSA, R. C. A. Salt balance in the substrate and growth of 'Tahiti' acid lime grafted onto Sunki mandarin hybrids under salt stress. Australian Journal of Crop Science, Brisbane, v. 9, n. 10, p. 954-961, Oct. 2015.

BRITO, M. E. B.; SÁ, F. V. S.; SOARES FILHO, W. S., SILVA, L. A.; FERNANDES, P. D.; Gas exchange and fluorescence of citrus rootstocks varieties under saline stress. Revista Brasileira de Fruticultura, Jaboticabal, v. 38, n. 2, p. 1- 8, Jun. 2016. https://doi.org/10.1590/0100-29452016951

FERNANDES, P. D.; BRITO, M. E. B.; GHEYI, H. R.; SOARES FILHO, W. dos S.; MELO, A. S.; CARNEIRO, P. T. Crescimento de híbridos e variedades porta-enxerto de citros sob salinidade. Acta Scientiarum Agronomy, Maringá, v.33, n. 2, p. 259-267, Jun. 2011. https://doi.org/10.4025/actasciagron.v33i2.5582

Ferreira, D.F. Sisvar: a computer statistical analysis system. Ciência Agrotecnologia 35: 1039-1042. 2011. https://doi.org/10.1590/S1413-70542011000600001

HUSSAIN, S.; LURO, F.; COSTANTINO, G.; OLLITRAULT, P.; MORILLON, R. Physiological analysis of salt stress behavior of citrus species and genera: Low chloride accumulation as an indicator of salt tolerance. South African Journal of Botany, Scottsville, v. 81, n. 1, p. 103- 112, Mar. 2012. https://doi.org/10.1016/j.sajb.2012.06.004

IBGE - Instituto Brasileiro de Geografia e Estatística. 2016. Levantamento Sistemático da produção agrícola: março de 2016. Disponível em: http://www.ibge.gov.br acesso [23 fevereiro 2017].

LEVY, Y.; SYVERTSEN, J. Irrigation Water Quality and Salinity. Effects in Citrus Trees. Horticultural Reviews, New Jersey, v. 30, n. 1, p. 37-82, Mar. 2004. https://doi.org/10.1002/9780470650837.ch2

LUCENA, C. C.; SIQUEIRA, D. L.; MARTINEZ, H. E. P.; CECON, P. R. Salt stress change chlorophyll fluorescence in mango. Revista Brasileira Fruticultura, Jaboticabal, v. 34, n. 4, p. 1245-1255, Dec. 2012. https://doi.org/10.1590/S0100-29452012000400034

MATTOS JUNIOR, D.; NEGRI, J.D. de; PIO, R.S; POMPEU JUNIOR, J. Citros. Campinas, Instituto Agronômico e Fundag, 929p. 2005.

OLIVEIRA, C. N.; CAMPOS, V. P.; MEDEIROS, Y. D. P. Avaliação e identificação de parâmetros importantes para a qualidade de corpos d'água no semiárido baiano. Estudo de caso: bacia hidrográfica do rio Salitre. Química Nova, São Paulo, v. 33, n. 5, p. 1059-1066, May. 2010. https://doi.org/10.1590/S010040422010000500010

RIBEIRO, R.V. Variação sazonal da fotossíntese e relações hídricas de laranjeira "Valência". Piracicaba, 2006. 157f. Tese (Doutorado em Agronomia / Física do Ambiente Agrícola) - Escola Superior de Agricultura "Luiz de Queiroz”, Universidade de São Paulo, Piracicaba, 2006. 
SÁ, F. V. S.; BRITO, M. E. B.; SILVA, L. A.; MOREIRA, R. C. L.; FERNANDES, P. D.; FIGUEIREDO, L. C. Fisiologia da percepção do estresse salino em híbridos de tangerineira-Sunki Comum sob solução hidropônica salinizada. Comunicata Scientiae, Bom Jesus, v. 6, n. 4, p. 463-470, Dec. 2015. https://doi.org/10.14295/cs.v6i4.1121

SÁ, F. V. S.; BRITO, M. E. B.; MOREIRA, R. C. L.; SILVA, L. A.; SOARES FILHO, W. S.; FIGUEIREDO, L. C.; GUEYI, H. R.; FERNANDES, P. D. Growth and physiology of citrus rootstocks under salt stress. Bioscience Journal, Uberlândia, v. 34, n. 4, p. 907-916, Jul./Aug. 2018. https://doi.org/10.14393/BJv34n1a2018-36553

SANTOS, R. T. Identificação e caracterização de corpos de água salinas no semi-árido paraibano. Campina Grande, Dissertação (Mestrado em Engenharia Agrícola), Universidade Federal de Campina Grande, 76p. 2008.

SILVA, F. V.; SOARES, F. A. L.; GHEYI, H. R.; TRAVASSOS, K. D.; SUASSUNA, J. F.; CARDOSO, J. A. F. Produção de citros irrigados com água moderadamente salina. Irriga, Botucatu, Edição Especial, n. 01, p. 396-407, May. 2012. https://doi.org/10.15809/irriga.2012v1n01p396

SILVA. L. A.; BRITO. M. E. B.; SÁ. F. V. S.; MOREIRA. R. C. L.; SOARES FILHO, W. S.; FERNANDES, P. D. Mecanismos fisiológicos em híbridos de citros sob estresse salino em cultivo hidropônico. Revista Brasileira de Engenharia Agrícola e Ambiental, Campina Grande, v.18, Suplemento, p. S1-S7, Dec. 2014. https://doi.org/10.1590/1807-1929/agriambi.v18nsupps1-s7

SYVERTSEN, J. P.; GARCIA-SANCHEZ, F. Multiple abiotic stresses occurring with salinity stress in citrus. Environmental and Experimental Botany, Oxford, v. 103, n. 1, p. 128-137, Jan. 2014.

https://doi.org/10.1016/j.envexpbot.2013.09.015

ZHAO, G. Q.; MA, B. L.; REN, C. Z. Growth, gas exchange, chlorophyll fluorescence, and ion content of naked oat in response to salinity. Crop Science, Madison, v. 47, n. 1, p. 123 - 131, Mar. 2007.

https://doi.org/10.2135/cropsci2006.06.0371 